\title{
Hazardous Substances and their Effects on Drinking Water Sources
}

\section{Šárka KROČOVÁ ${ }^{1)}$}

\author{
1) VSB-Technical University of Ostrava, Faculty of Safety Engineering, 70013 Ostrava-Výškovice, Lumírova Str. 13, Czech Republic; \\ email: sarka.krocova@vsb.cz
}

http://doi.org/10.29227/IM-2021-01-01

Submission date: 03-01-2021 | Review date: 23-05-2021

\section{Abstract}

Drinking water cannot be produced from every raw surface or groundwater in the European Union countries. The source must meet the set criteria for the raw water quaility. At present time, drinking water sources meet these requirements. However in the climate change period, accompanied in particular by long-term loss of water volumes, the set limit values for individual categories of raw water may be frequently exceeded. Human society must be prepared for this threat and take legislative and technical-operational steps in a timely manner to eliminate the risk. This paper deals with the issue in the basic scope and declares what producers and steps can be used in practice to increase the resilience of water resources to the expected change in the water quality.

Keywords: hazardous substances, drinking water sources, water quality, threat extent reduction, prevention

\section{Introduction}

Harmful, dangerous or particulary dangerous substances in water have the potential to endager human health and lives. This is not just a theoretical threat but still a real danger to statistics of individual countries or regions in the world. For example in technically and culturally advanced Europe, nearly 13.5 thousand children under the age of fourteen died in 2001 due to poor drinking water quality [1]. Outside Europe these numbers are even more threatening. With the coming climate change acoording to the United Nations predictions, the world's water stress will suffer but to 3.9 miliard people [2].

It will be possible to reduce this real threat, not only by rational use of existing water resources and their expansion but also by grater emphasis on preventing surface and groundwater contamination with harmful substances. At the same time these statistics will almost certainly increase with the rapidly growing human population in Africa and a big part of Asian countries as well. Given that this predictions do not indicate a reduction in the growth rate of world's human population in the foressable future, the issue must be addressed differently. One of the possibilities is to search for new ways leading to the drinking water resources protection and their abundance in accordance with new scientific knowledge and technical possibilities of individual states in the whole world. The following chapters suggest that the solution can be implemented under the conditions of early risk awareness, its extent and means leading to its own elimination.

Water resources in the new climatic conditions of the 21 st century

Water resources suitable for the treatment of raw water into drinking water are very unevenly distributed in the world. Most of them are located in relatively sparsely populated areas of the world such as Scandinavia and other water-rich areas. Altough these areas have a relative surplus of quality fresh raw water they do not meet other suitable conditions for human life, especially in terms of farming and housing constuciton with ad- vanced public and private infrastructure, enabling a high standard of human life [3].

Due to the uneven occurence of drinking water sources on the Earth and requirements of their use for the ever increasing human population in the major regions in the world, a further increace in imbalance between requirements and natural possibilities can be expected. In addition to human population growth the current imbalance will be significantly exacerbated by climate change [4].

Its action will affect the most of natural resources that condition current human life and its needs, especially water resources. The significant decrease in water supplies at potential and real sources by up to tens percent of the original capacity can be already documented. Depending on aquatic ecosystems types and their usability for water supply purposes, climate change during the predominantly entire of the whole 21 st century is likely to manifest itself in the following manner and negation extent.

\section{Drinking water surface sources}

Surface sources of drinking water will be the most important water sources in the new climatic conditions. Their importance will certainly increase with the expected reduction in groundwater volumes. However compared to groundwater, they are also more vulnerable to natural influences or anthropogenic events.

In surface water there are two main natural pollutants, two types of impuritites; dissolved high molecular weight organic substances and undissolved colloidal substances. Both pollutant groups cannot be removed from water directly by mechanical processes such as sedimentation and filtration. The particles and substances are stabilized against larger units. The main stabilization mechanisms consist of an electric double layer and a hydration cover, see figures 1 and 2.

However surface water, unlike some groundwater types, must always be treated for drinking water quality parametres. The aim of the water properties treatment is to achieve such 


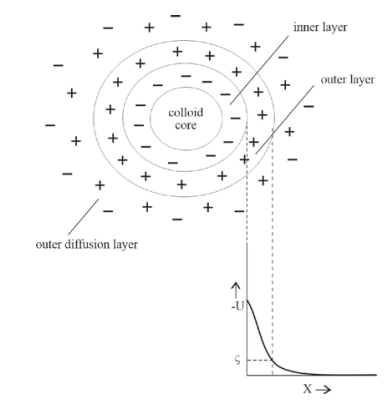

Fig. 1. Electronic double-layer [5]

Rys. 1. Podwójna warstwa elektornowa

quality parametres of threated water as the requirements for drinking water quality in terms of its further use in the water supply processes are met. After the drinking water treatment the surface water is used as a basic medium especially for water supply systems of group and regional water mains.

\section{Drinking water underground sources}

Groundwater in general has and will continue to be irreplaceable importance for flora, fauna and also for the human population. If flora and fauna are completely existential condition for a life then in human areas they can be replaced by surface water in some built-up areas. Although in the case of scattered and other buildings they will continue to be an irreplaceable condition for people axistence in the area and technical infrastructure function of built-up areas.

Groundwater in general has diferent physical properties and composition compared to surface water. To a greater extent iron and manganese are present in dissolved form, as a simple hydrated cations $\mathrm{Fe}^{2+}$ and $\mathrm{Mn}^{2+}$. Iron is present in groundwater in concentrations usually up to $5 \mathrm{mg}-1$. The manganese concentration is usually lower. Both substances must be removed or their content must be reduced in the process of treating raw water to drinking water. In technological processes for the iron and manganese removal from water, Fe and $\mathrm{Mn}$ are converted into an insoluble compound which is further separated from water by conventional methods such as sedimentation and filtration.

Insoluble compounds are prepared by oxidation of $\mathrm{Fe}$ and $\mathrm{Mn}$ to higher forms according to the reaction:

$\mathrm{Fe}^{2+}+3 \mathrm{H}_{2} \mathrm{O}-\mathrm{e}=\mathrm{Fe}(\mathrm{OH})_{3}+3 \mathrm{H}^{+}$

$\mathrm{Mn}^{2+}+3 \mathrm{H}_{2} \mathrm{O}-2 \mathrm{e}=\mathrm{MnO}(\mathrm{OH})_{2}+4 \mathrm{H}^{+}$

For oxidation atmospheric oxygen dissolved in water, chlorine, potassium permanganate or ozone is used as the oxidizing agent. The above mentioned substances of natural occurence in groundwater will increase during climate change and its consequences on aquatic ecocystems including the consequent need to eliminate them.

Except these substances it can be expected increased amount of following other udesirable substances in surface and groundwater:

- toxic or persistant organic compounds of various substances,

- inorganic compounds of phosphorous or elemental phosphorous,

- $\quad$ silage juices, industrial livestock, fertilizers,
- fluorides,

- organohalogen and organophosphorous compounds,

- mercury and its compounds,

- cyanides.

The expected increased concentrations of these above mentioned and other substances will significantly change the current natural quality of surface and groundwater to worse result. In many cases it will be neccessary to change or reconstuct existing drinking water treatment plants, given that their technology will not have the potential to treat raw, more polluted water with undesirable substances into drinking water. Due to the fact that drinking water is a completely dominant prerequisite for maintaning human health and lives, it has to meet the number of limiting and limit values. These are mainly microbiological and biological indicators, physical, chemical and organoleptic indicators and radiological indicators.

The very important part of maintaining water quality and its control is the frequency of drinking water analyzes. It will be necessary to increase drinking water quality in the water supply system compared to the current state. The primary reason will be among other things an increase in the average air and soil temperature in which water supply facilities are located as well as the expected change in the hydraulic load of drinking water mains distribution systems for public use.

\section{Ways of eliminating threats of drinking water disposal sourc- es by hazardous substances}

Maintaining the volumetric and hydraulic yield of drinking water sources will probably be one of the most important and also very difficult tasks of the human population for at least the next decades. The result will depend mainly on two facotrs:

- climatic and meteorological conditions,

- anthropogenic threats to aquatic ecosystems.

The first factor cannot be influenced by people except in exceptional cases. However with sufficient prevention of its occurence the extent of consequences can be eliminated. The second factor and the extent of its negation in the natural environmnet including its negative impact on aquatic ecosystems, is entirely within the human capabilities and competence of the state administration, in the area of potential risk elimination and threats extent.

\section{Climatic and meteorological conditions}

Climate change and meteorological conditions cannot be significantly influenced by human population. In the pre- 


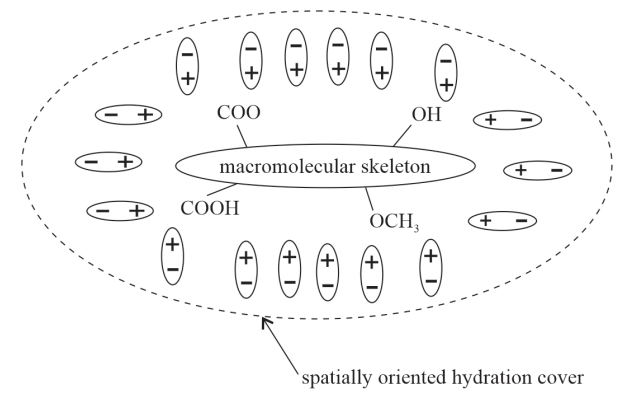

Fig. 2. Hydration cover of humic substances macromolecule [5]

Rys. 2. Pokrycie hydratacyjne makrocząsteczki substancji humusowych [5]

vention and alternative changes reductions some positive and negative phenomena can be used to mitigate the consequences. In water management and in aquatic ecosystems environment these are mainly the following options.

Reducing negative properties range of climatic change

- some current land deactivation of reclamation structures on agricultural land in order to prevent the outtflow of rainfall from the area (drainage systems, drainage ditches),

- $\quad$ surface water flow speed reduction in water recipients through newly realized water work (weirs, rafts, new meanders),

- fundamental change of management on agricultural and forest lands, especially in the form of land cultivation and secondary management in individual river basins, depending on the real environment and local climatic conditions (planting other tree species, fundamental change of agricultural crops, significant product reduction)

\section{Natural phenomena utilization of new climatic conditions}

- $\quad$ significant volume retention of extreme rainfall in landscape, resulting from new climatic condition manifestations (local inflitration ditches on forest and agricultural land, areas for artifical lake creation, wetlands),

- new artifical systems construction of artifical infiltration into shallow aquifers, in order to create possibility of capillary moisture in the soil environment and subsequent higher usability for agriculture (infiltration ditches, soil watering equipment, shallow wells),

- use to increase average air temperature to grow new plants and tree species and at the same time abandon the original already unsuitable crops for the newly created climatic conditions in regions (shallow rooted crops, agricultural products with high requirements for permanent soil moisture)

- usage of surface and gorund water for water supply needs for implementation to carry out anew hydrogeological survey of the area with the aim for finding weaknesses of the given area and possibility of retention strengthening and precipitationwater supply use, soil environment geological knowledge, possibility of increasing inflitration to surface water from recipients).
Both above mentioned options must be closely linked to anthropogenic potential threats arising in particular from human activity in industrial agglomerations [6]. The inter relationships of natural influences and anthropogenic events will tend to increase their negative effects when reducing the surface and groundwater volumes.

\section{Anthropogenic threats to aquatic ecosystems}

Adressing the negative effects and anthropogenic influences effects on aquatic ecosystems it is entirely within human capabilities [7]. The current scientific knowledge and technical possibilities of most countries in the world allow their solution to a sufficient extent in two basic ways.

\section{Passive approaches to reducing the extent and anthropogen- ic threats consequences}

- treatment processes efficiency increasing of existing wastewater treatment plants (urban and industrial wastewater treatment plants),

- current creation change of protection zones concerning water sources with the aim of significantly increasing absorption potentials in the protection zone in question (retention or harmful, dangerous organic and inorganic substances and their subsequent reduction),

- new passive elements construciton of temporary primary retention of harmful floating substances in the upper watercourses recipients (floating submerged walls, oil separators).

Active possibilities and prevention in the elimination area of anthropogenic threats to aquatic ecosystems

- elements construction and equipment limiting or completely preventing groundwater contamination (Milan walls, hydraulic barriers, monitoring wells),

- revision and significant change in the area of water management and its use in water supply and for agricultural and energy purposes (higher degree of interconnection with the crisis law, elements of critical infrastructure and ensuring emergency supply of natural elements and irreplaceable infrastructure of area with drinking water),

- $\quad$ setting out their responsibilities in the area of ensuring the long-term aquatic ecosystems sustainability and increasing current insufficient hydraulic parameters of water supply network and technical and operational other water works paramters. 
The need to implement above mentioned model measures resulting from the threat of water scarcity to implement and maintain raw water quality in aquatic ecosystems have to become one of the human population primary tasks. Given that the task extends to a very wide range of human life and individual states infrastructure it is necessary to have a broad discussion on the topic.

\section{Discussion}

At the same time the expert and public discussion could be focused mainly on the following topics:

- current scientific knowledge evaluation on the threats posed by slimate change to different types of areas and their geological composition,

- new progressive methods development of risk analysis for water resources and water supply systems for public use,
- $\quad$ finding ways to apply new possibilites into practice in an economically feasible dimension and the maturity of human population individual states.

\section{Conclusion}

These presented procedures and proposed solutions aim to expand the existing discussion on already ongoing climate change and at the same time can contribute to a more comprehensive approach to risk assessment and its consequences in underestimatig the threat. The solved problem has a national and international character and it is necessary to aproach the interdisciplinary problém comprehensively [8].

Humanity no longer has much time to solve. However at the same time it has sufficient knowledge and also opportunities to eliminate the threat and its consequences properly and well-timed.

\section{Literatura - References}

1. KOŽÍŠEK, F.: Hygienické minimum pro pracovníky ve vodárenství, SZÚ, Praha 2006.

2. INFORMATION AND EXTERNAL RELATIONS DIVISION OF UNFPA AND UNITED NATIONS POPULATION FUND (2011). State of World Population 2011: people and possibilities in a world of 7 billion. New York: United Nations Publication Fund. ISBN 978-08-9714-990-7.

3. KROČOVÁ, Šárka, BOUCHALOVÁ, Markéta. Climate changes and their impact on the surface water quality. In Water, reosurces, forest, marine and ocean ecosystem conference proceedings. Vol I. Sofia. STEF92 Technology LDT, 2016, s. 161-167. ISBN 978-619-7105-61-2.

4. GARNIER, Monica, HARPER, David, BLASKOVICOVA, Lotta, et.al.: Climate Change and European Water Bodies, a review of Existing Gaps and Future Research Needs: Findings of the Climate Water Project. Environmental management[online]. 56 (2), 271-275 [cit. 2019-08-21]. ISSN 0364-152x.]

5. STRNADOVÁ, N., JANDA, V. : Technologie vody I. VŠCHT, Praha 1999. ISBN 80-7080-348-7.]

6. KROCOVA, S. 2017 Industrial Lanscape in the Period Drought.InženieraMineralna 2017 vol. 39. No. 1 p 39-32 ISSN 1803-569-8X.

7. BLAZKOVA, K., POKORNY, J., CABLIK, V. Improving the Environmental Safety by Means of Chemical Monitoring System. Inžynieria Mineralna - Journal of the Polish Mineral Engineering Society. Krakow: Polish mineral engineering society. 2015, vol. 36, N. 2, s. 37 - 43. ISSN 1640-4920.

8. KAVAN, Š., BREHOVSKÁ, L. Cooperation of South Bohemia and Cross-Border Regions with a Focus on Civil Protection. In Klímová, V., Žítek, V. (eds.) 19th International Colloquium on Regional Sciences. Conference Proceedings. Brno : Masarykova univerzita, 2016. pp. 907-914. ISBN 978-80-210-8273-1. DOI: 10.5817/CZ.MUNI. P210-8273-2016-117.

\footnotetext{
Abstrakt

Woda pitna nie może być produkowana z każdej surowej wody powierzchniowej lub gruntowej w krajach Unii Europejskiej. Źródło musi spetniać określone kryteria jakości wody surowej. Obecnie te wymagania spetniaja źródła wody pitnej. Jednak w okresie zmian klimatu, którym w szczególności towarzyszy długotrwała utrata objętości wody, ustalone wartości graniczne dla poszczególnych kategorii wód surowych moga być często przekraczane. Społeczeństwo ludzkie musi być przygotowane na to zagrożenie i podejmować $w$ odpowiednim czasie kroki legislacyjne i techniczno-operacyjne w celu wyeliminowania ryzyka. W niniejszym opracowaniu poruszono zagadnienie w podstawowym zakresie i deklaruje, jakie producenci i jakie kroki można zastosować w praktyce, aby zwiększyć odporność zasobów wodnych na oczekiwaną zmianę jakości wody.
}

Słowa kluczowe: substancje niebezpieczne, źródła wody pitnej, jakość wody, zmniejszenie zasiegu zagrożenia, zapobieganie 